\title{
2014. évi demográfiai adatok gyermekgyógyászoknak
}

\author{
2014 Hungarian demographic data for paediatricians
}

\author{
Szerző: $\quad$ Dr. Valek Andrea $\square$ \\ Nemzeti Egészségfejlesztési Intézet
}

\begin{abstract}
Kulcsszavak: demográfia; gyermek; újszülött; csecsemő, termékenység, élveszületés, halálozás
\end{abstract}
Keywords: demography; child; newborn; infant; fertility, live birth, mortality

\begin{abstract}
A lakosság egészségi állapotának felméréséhez ismeretekkel kell rendelkezni az érintett népesség demográfiai jellemzőiről is. Hazánkban 2014-ben több népmozgalmi folyamatban is kedvező irányú változás következett be az előző évihez képest: emelkedett a születések száma, kevesebb halálozás történt, számottevően csökkent a terhesség-megszakítások száma, és az eddigi legalacsonyabb volt a csecsemőhalálozás. Jelen beszámoló egy előzetes bemutató, a később elkészülő részletes elemzés és a korábbi évek adatai a www.ogyei.hu honlapon érhetőek el.
\end{abstract}

\section{A GYERMEKNÉPESSÉG SZÁMA, ARÁNYA}

A magyar 0-14 éves korú gyermekek száma 1990 óta folyamatosan csökken, 1993-ban kétmillió alá került, 2015. január 1-jén 1427186 volt. [1. ábra] A 0-14 évesek teljes népességen belüli aránya az 1990-es 20,5\%-ról 2015-re 14,5\%-ra csökkent.

1. ábra: A 0-14 éves népesség számának és arányának alakulása, 1990-2015

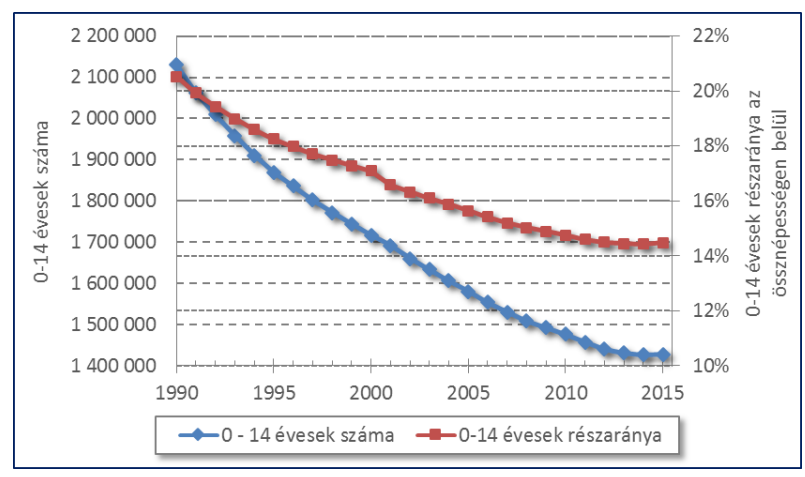

\section{ÉLVESZÜLETÉS}

Az élveszületések száma először 1998-ban süllyedt százezer alá, a mélypontot a 2011. évi születésszám jelentette. 2014-ben 91510 magzat jött a világra, amely az életnek valamilyen jelét adta; ez az elmúlt öt év legmagasabb születésszáma. Az újszülöttek súlya az egyik legfontosabb csecsemőhalálozást befolyásoló tényező. A kis súlyú újszülöttek, a 2500 grammnál kisebb súllyal születettek aránya nagyon magas, az utóbbi tizenöt évben nem mutatott csökkenést, értéke $8,9 \%$ volt.A nem házas családi állapotúak részaránya folyamatosan emelkedik a szülő nők között, 2014-ben az újszülöttek majdnem fele, 47,6\%-a született házasságon kívüli kapcsolatból, amely az eddigi legmagasabb részarány. [2. ábra] A 2014-es születésszám növekedés több mint 90\%-a a házasságon kívüli születések nagyobb mértékű emelkedéséből eredt. A szülő nők életkora egyre határozottabban kitolódik, a nők átlagos életkora a gyermekük születésekor

2. ábra: Élveszületések számának alakulása az anya családi állapota szerint, 1990-2014

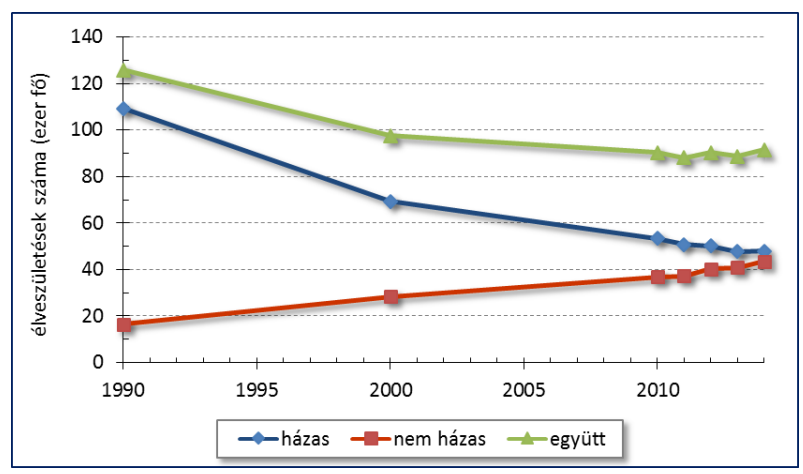


2014-ben 30,14 év volt. A 2014. évi születésszámemelkedés a szülőképes korú nők létszámának csökkenésével párhuzamosan ment végbe, és mivel a 44 év feletti nők kivételével valamennyi korcsoportban nőtt a születések száma, így a termékenység is. Míg 1990-ben a 20-24 éves korcsoportban, 2000-ben a 25-29 éves korcsoportban, ezt követően már a 3034 éves korcsoportban volt a legmagasabb a korspecifikus termékenység. [3. ábra] 2010 óta az összes újszülött több mint felét a 30 éves és ennél idősebb nők vállalják, 2014-ben arányuk 53,7\%-ot tett ki.

\section{MAGZATI VESZTESÉGEK}

A magzati halálozások száma, ami a spontán vetélésék és halvaszületések együttes számát jelenti, ugyan jelentéktelen mértékben csökkent az utóbbi évtizedben, de a 100 élveszületésre vonatkoztatott aránya növekedést mutat, bár 2011 óta már csökkenő tendencia figyelhető meg. [4. ábra] 1990-től a terhességmegszakítások aránya folyamatosan csökken, 2014-ben 100 élveszülöttre 35,7 terhességmegszakítás jutott.

\section{SZÜLETÉS KÖRÜLI HALÁLOZÁS}

A születés körüli halálozási arányszám változásának tendenciája csökkenő, nagyobb részét a késői magzati halálozás adja. [5. ábra] 2014-ben 1000 születésre 6,3 perinatális halálozás jutott, 421 volt a halvaszülöttek, 161 a 0-6 napos korban meghaltak száma.

\section{CSECSEMŐHALÁLOZÁS}

1990-ben 1000 élveszülöttre közel 15 halott csecsemő jutott, azóta a csecsemőhalandóság folyamatosan csökkent, 1997 óta az értéke 10 ezrelék alatt van, 2011-ben pedig az egy éven aluliak mortalitása 5 ezrelék alá került. [6. ábra] 2013-ban a javuló irányzat megtorpant, és ismét 5 ezrelék fölé emelkedett az értéke. 2014-ben 1000 élveszülöttre 4,6 egy éves kora előtt elhunyt gyermek jutott. 2015-ben tovább csökkent a csecsemőhalandóság, az ez évi érték - 4,1 ezrelék - az eddigi legalacso-
3. ábra: Ezer megfelelő korú nőre jutó élveszületés, 1990-2014

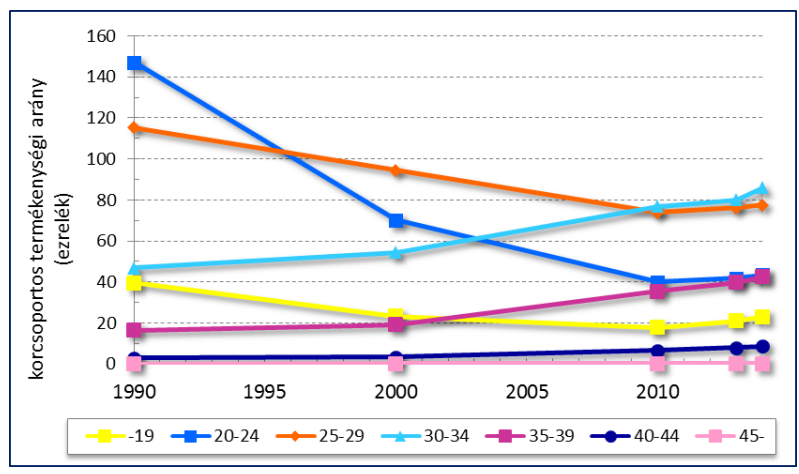

4. ábra: Magzati veszteségek alakulása, 1990-2014

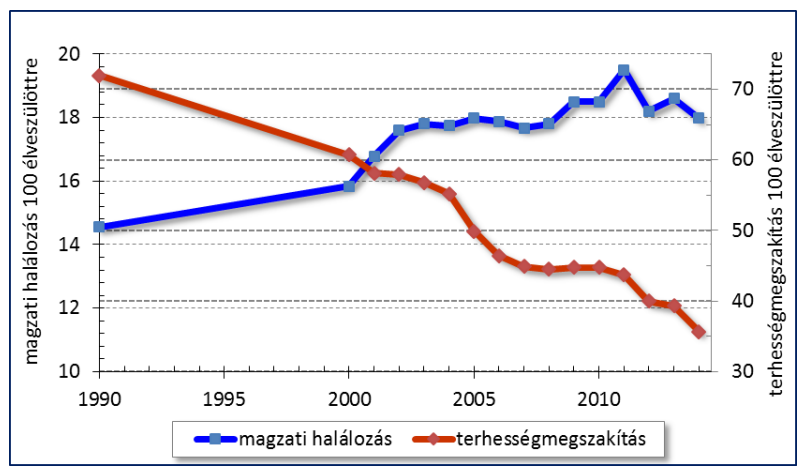

5. ábra: Születés körüli halálozás alakulása, 1990-2014

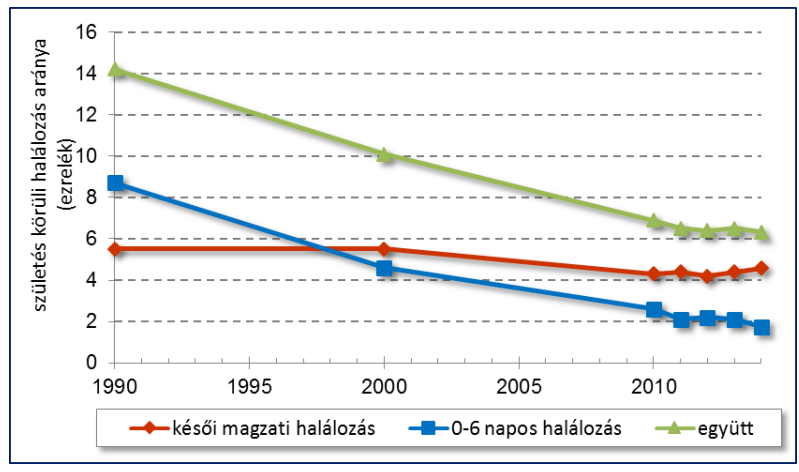

6. ábra: Csecsemőhalandóság alakulása, 1990-2015

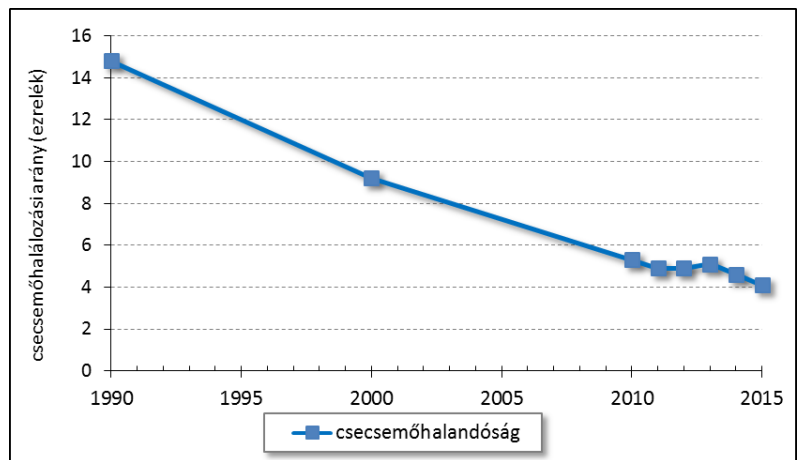


nyabb hazánkban. A csecsemőhalálozás összefüggése a szülők, elsősorban az anya iskolázottságával bizonyítottnak tekinthető. A középfokú és felsőfokú iskolai végzettséggel rendelkező anyák újszülötteinek halandósága alacsonyabb, mint az átlagos csecsemőhalandóság. Az általános iskolát be nem fejező anyák csecsemőinek a halálozása több mint négyszerese volt a legmagasabb iskolai végzettségú anyák csecsemői körében mért halálozási szintnek. [7. ábra] A csecsemőhalandóság terén nagy területi egyenlőtlenségek alakultak ki Magyarországon. Megyei összehasonlításra a három évre összevont csecsemőhalálozási arányszám alkalmas. A 2012-2014es évre összevont arányszám országos értéke 4,85 ezrelék volt. [9. ábra] Nagyon kedvező, 4 ezrelék alatti érték jellemezte Budapestet, Pest, Csongrád valamint Hajdú-Bihar megyét. Ennek kétszerese volt Somogy és Borsod-Abaúj-Zemplén megyében a csecsemőhalandóság.

\section{GYERMEKHALANDÓSÁG}

A csecsemők viszonylag magasabb halandóságához képest a kisgyermekeké egyre csökken, a legalacsonyabb 5-9 éves korban, ezt követően különböző intenzitással folyamatosan emelkedik a halálozás az egyes korcsoportokban. A halálokok megoszlását mutatja a haláloki struktúra, de gyakoriságra nem következtethetünk belőle. 2014-ben a csecsemők 56\%-a a perinatális szakban keletkező kórállapotok miatt halálozott el, 28\%-uk veleszületett fejlődési rendellenességek következtében vesztette életét. [8. ábra] Gyermekkorban a halálesetek 80\%-áért a daganatok, az idegrendszer betegségei, fejlődési rendellenességek és külső okok felelősek. Az életkor növekedésével a halálesetek egyre nagyobb részét okozzák az elkerülhető külső okok - vagyis a balesetek, gyilkosságok és öngyilkosságok.

7. ábra: Csecsemöhalandóság az anya iskolai végzettsége szerint, 2014

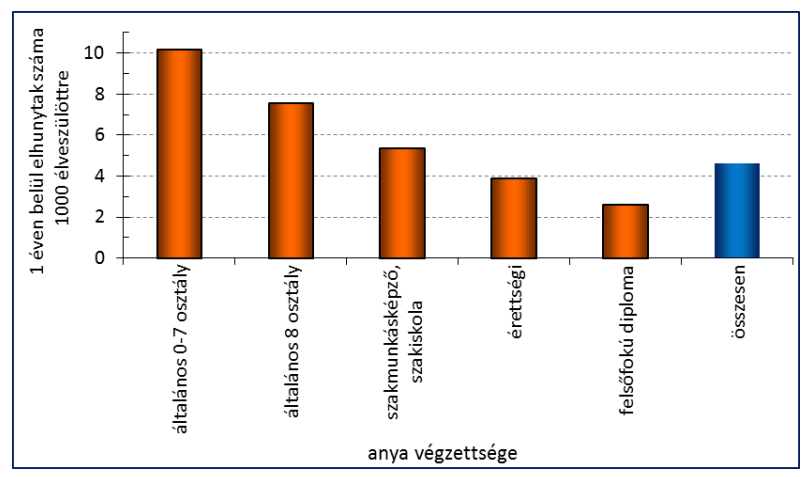

8. ábra: Vezető halálokok egyes életkori csoportokban, 2014

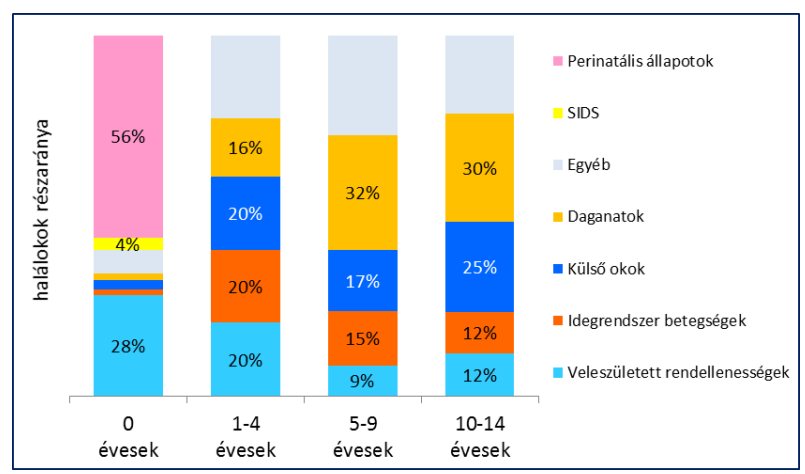

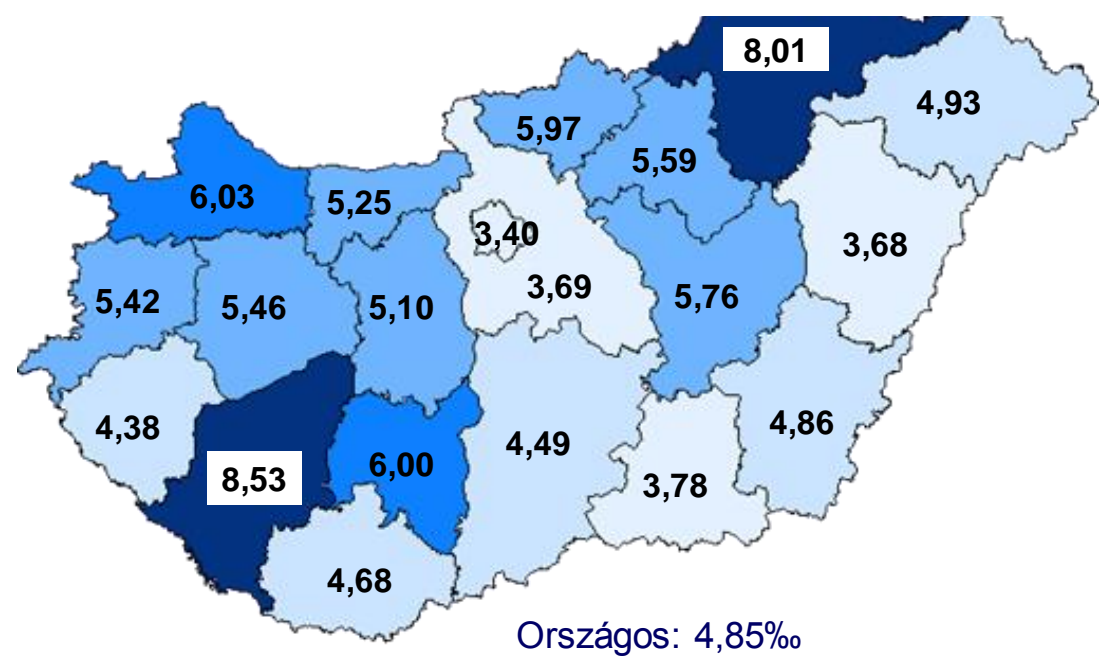




\section{EURÓPAI ÖSSZEHASONLÍTÁS}

1. táblázat: Magyarországi gyermeknépesség demográfiai adatainak összehasonlítása az európai országok megfelelő értékeivel

\begin{tabular}{|c|c|c|c|c|c|}
\hline & Magyarország & $\begin{array}{l}\text { Magyarország } \\
\text { helyezése (beso- } \\
\text { rolható orszá- } \\
\text { gok száma)* }\end{array}$ & $\begin{array}{l}\text { Európai orszá- } \\
\text { gok együtt }\end{array}$ & $\begin{array}{l}2004 \text { előtt csat- } \\
\text { lakozott EU or- } \\
\text { szágok együtt }\end{array}$ & $\begin{array}{l}2004 \text { után csat- } \\
\text { lakozott EU or- } \\
\text { szágok együtt }\end{array}$ \\
\hline $\begin{array}{l}\text { Élveszületési arány- } \\
\text { szám }\end{array}$ & $9,0 \%$ & 7. (52) & $12,3 \%$ & $10,1 \%$ & $9,6 \%$ \\
\hline $\begin{array}{l}\text { Csecsemőhalálozási } \\
\text { arányszám }\end{array}$ & $5,1 \%$ & 24. (36) & $7,0 \%$ & $3,3 \%$ & $5,4 \%$ \\
\hline $\begin{array}{l}\text { Születés körüli halálo- } \\
\text { zási arányszám }\end{array}$ & $3,9 \%$ & 15. (45) & $7,3 \%$ & $6,3 \%$ & $4,7 \%$ \\
\hline $\begin{array}{l}1000 \text { élveszülöttre jutó } \\
\text { abortusz }\end{array}$ & 393 & 37. (41) & 234 & 218 & 203 \\
\hline $\begin{array}{l}\text { Kis súlyú újszülöttek } \\
\text { aránya }\end{array}$ & $8,8 \%$ & 46. (50) & $6,8 \%$ & $7,3 \%$ & $7,2 \%$ \\
\hline
\end{tabular}

*Azok az európai országok szerepelnek a listában, ahol a 2013. vagy a 2012. évi adatok elérhetőek voltak.

\section{ADATFORRÁSOK}

Demográfiai évkönyv, 2014; Központi Statisztikai Hivatal

Tájékoztatási adatbázis, Központi Statisztikai Hivatal; http://statinfo.ksh.hu/Statinfo/index.jsp European health for all database, Updated: December 2015; WHO Regional Office for Europe 